The Family: Change or Continuity? 


\section{The Family: Change or Continuity?}

Faith Robertson Elliot

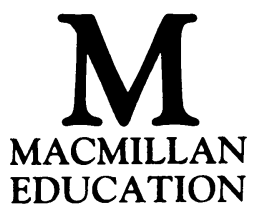


All rights reserved. No reproduction, copy or transmission of this publication may be made without written permission.

No paragraph of this publication may be reproduced, copied or transmitted save with written permission or in accordance with the provisions of the Copyright Act 1956 (as amended).

Any person who does any unauthorised act in relation to this publication may be liable to criminal prosecution and civil claims for damages.

First published 1986

Published by

MACMILLAN EDUCATION LTD

Houndmills, Basingstoke, Hampshire RG21 2XS and London

Companies and representatives

throughout the world

British Library Cataloguing in Publication Data

Elliot, Faith Robertson

The Family: change or continuity?

1. Family-Social aspects

I. Title

306.8'5'091821 HQ7B4

ISBN 978-0-333-32970-2

ISBN 978-1-349-18442-2 (eBook)

DOI 10.1007/978-1-349-18442-2

ISBN 978-0-333-32970-2 Pbk 
For my family 


\section{Contents}

List of Tables and Figures $\quad \mathbf{x}$

Acknowledgements $\quad$ xi

1 Introduction 1

1.1 What is the family? 4

1.2 Sociology and the family $\quad 8$

2 Family Structures: Biological or Social?

2.1 The nuclear family 16

2.2 The needs of the child 20

2.3 The sexual division of labour 25

2.4 Summary 32

3 The Development of the Modern Family 34

3.1 A functionalist approach: the work of Talcott Parsons 35

Parsons' thesis 35

Parsons challenged $\quad 38$

3.2 Empirical accounts $\quad 42$

Kinship in decline? 43

The changing role of the family 52

Summary $\quad 59$

3.3 Marxist approaches 61

Engels $\quad 62$

Contemporary accounts 63

The critics $\quad 65$

3.4 Ideation and the conjugal family 68 
4.1 The nature and direction of change

The pre-industrial period: the economic partnership of husband and wife

The industrial period: the amplification of the housewife-mother role

The post-Second World War period: a more

$$
\text { symmetrical division of labour? }
$$

82

4.2 Theoretical perspectives

Functional for the family and society? 99

Supportive of capitalism?

In the interests of men?

The marriage of Marxism and feminism

5.1 A haven?

5.2 A prison?

An instrument of capitalist oppression?

Oppressive of individuality?

An agency for the oppression of women?

5.3 A haven and a prison?

\section{Remodelling the Conjugal Family}

6.1 The institutionalisation of divorce 134

The introduction and liberalisation of divorce law $\quad 135$

The incidence of divorce

Explaining the resort to divorce 142

The divorce experience

6.2 One-parent families 151

Structural characteristics $\quad 156$

Tensions and contradictions $\quad 167$

$\begin{array}{ll}6.3 \text { Remarriage families } & 169\end{array}$

$\begin{array}{ll}\text { Structural characteristics } & 170\end{array}$

The vulnerability of remarriage families $\quad 173$

6.4 How much change? 175 
7.1 The development of alternative life-style ideologies

7.2 Cohabitation

Structural characteristics

Sources of tension

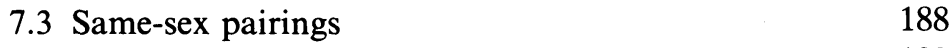

$\begin{array}{ll}\text { Structural characteristics } & 189\end{array}$

Sources of tension 195

7.4 Group living 196

Structural characteristics $\quad 197$

Sources of tension $\quad 200$

7.5 Family alternatives: a success story? 202

The failure of the alternative-life style endeavour $\quad 203$

The pro-family movement 205

8 Epilogue 207

Bibliography $\quad 211$

Author Index $\quad 224$

Subject Index 229 


\section{List of Tables and Figures}

\section{Tables}

4.1 Post-Second World War fertility trends: England and Wales

4.2 Mean age of women at birth of first child in marriage, England and Wales, 1973 and 1983

4.3 Representation of women in trade unions

4.4 Female membership of selected professional institutes or associations, 1983

4.5 Appointments to public bodies, 1983

6.1 The increase in divorce in England and Wales, 1911-83

6.2 Grounds on which divorce was granted, England and Wales, 1983

6.3 Social class variations in divorce, England and Wales, 1961

6.4 Social class variations in divorce in England and Wales, 1979

6.5 Families with dependent children by type and, for lone mothers, by marital status: Great Britain, 1971-83

6.6 One- and two-parent families by main source of income: Great Britain, 1979

7.1 Percentage of women who were married or cohabiting at the time of the survey, by age group: selected countries of Western Europe

Figures

6.1 Divorce rates: international comparisons

6.2 Legitimate live births: by conception inside or outside marriage, social class of father and age of mother, 1973 and 1981, England and Wales

6.3 Extra-marital conceptions by outcome, 1971 and 1981, Great Britain 


\section{Acknowledgements}

Robert Chester, Paul Close, Janet Finch, Chris Harris and David Morgan read first or early drafts of particular chapters of this book, while Stephen Edgell, John Selby and Nick Tilley read the penultimate draft of the whole. I am grateful to them all for their constructive, albeit sometimes critical, but always useful comments, for their time and encouragement. There are others who in different ways have also contributed to the production of this book and whom I wish to thank: Robert C. Elliot for stimulating my interest in current developments in family law; my colleagues in the Department of Applied Social Studies, Coventry (Lanchester) Polytechnic - in particular Ken Blakemore, Juliet Edmonds and Brian Ranson, and Robert Gingell in the Department of Legal Studies - who share my interest in the family and in gender for the discussions I have had with them in general or on particular chapters; my students for their interest in this project, in particular Derek Smith and Dave Richardson who commented on one chapter from a student viewpoint; the Polytechnic Library staff for their exceptional helpfulness, courtesy and efficiency; and Sue Page for the equability and skill with which she deciphered my nearly illegible handwriting, typed and retyped the early drafts and produced the final typescript.

FAITH Robertson Elliot

The author and publishers wish to thank those who have kindly given permission for the use of copyright material in charts and tables, namely: The British Journal of Sociology and Routledge \& Kegan Paul for Table 6.3; The Equal Opportunities Commission for Tables 4.3, 4.4 and 4.5; The Controller of Her Majesty's Stationery Office for Tables 4.1, 6.6 and 7.1 and for Figures 6.2 and 6.3; Population Studies for Table 6.4; The Registrar General for Tables 6.2 and 6.5; The Statistical Office of the European Communities for Figure 6.1. 